\title{
Partisipasi Masyarakat dalam Peningkatan Kualitas Pendidikan Agama Islam (PAI) di Madrasah
}

\author{
Rusyaid \\ Dosen Institut Agama Islam Negeri Sorong \\ rusyaidkajuara@yahoo.co.id
}

\begin{abstract}
The community is a group unit that is closely related and has the same interests. Society is seen as the basic capital of development, which if we develop it, it will contribute greatly to development. His involvement in implementing educational policies is the manifestation of the use and utilization of basic development capital. The community as service users and educational institutions has an obligation to develop and maintain the sustainability of the educational process. Ordinary people may mean that participation is a form of contribution, role or participation of someone in a certain activity. Participation cannot be interpreted only as the formality of someone's participation, but there must be concrete evidence or concrete action that the person or group helps to make a particular activity successful. Community participation in improving the quality of madrasah educational institutions is needed. Through the participatory method, encouraging everyone into a group process regardless of age, gender, social status or educational background.
\end{abstract}

Keywords: Urgency, Community Participation, and Madrasas. 


\begin{abstract}
Abstrak: Masyarakat merupakan satu kesatuan golongan yang berhubungan tetap dan mempunyai kepentingan yang sama. Masyarakat dipandang sebagai modal dasar pembangunan, yang apabila kita kembangkan maka akan besar sumbangannya terhadap pembangunan. Keterlibatannya dalam melaksanakan kebijaksanaan pendidikan adalah manivestasi dari pemanfaatan dan pendayagunaan modal dasar pembangunan. Masyarakat selaku pengguna jasa dan lembaga pendidikan memiliki kewajiban untuk mengembangkan serta menjaga keberlangsungan penyelenggaraan proses pendidikan. Masyarakat awam mungkin mengartikan bahwa partisipasi merupakan bentuk sumbangan, peran atau keikut sertaan seseorang dalam suatu kegiatan tertentu. Partisipasi tidak bisa diartikan hanya sebagai keikutsertaan seseorang secara formalitas saja melainkan harus ada bukti nyata atau aksi nyata bahwa orang atau kelompok tersebut ikut membantu menyukseskan suatu kegiatan tertentu. Partisipasi masyarakat dalam peningkatan kualitas lembaga pendidikan madrasah sangat dibutuhkan. Melalui metode partisipasi, mendorong setiap orang ke dalam suatu proses kelompok dengan tidak memandang umur, jenis kelamin, status sosial maupun latar belakang pendidikan.
\end{abstract}

Kata Kunci: Urgensi, Partisipasi Masyarakat, dan Madrasah.

\title{
Pendahuluan
}

Pendidikan merupakan kebutuhan yang sangat pokok dalam membentuk kepribadian peserta didik. Dengan adanya pendidikan masyarakat dianggap sebagai pelaksana program pendidikan yang pertama. Oleh karena itu, orang tua (masyarakat) sebagai penanggung jawab pendidikan berhak memilih pendidikan yang akan dipilih dalam menentukan pendidikan peserta didik.

Undang-undang Sistem Pendidikan Nasional pasal 8 UU No. 20 Tahun 2003 masyarakat berhak berperan serta dalam perencanaan, pelaksanaan, pengawasan dan evaluasi program pendidikan. ${ }^{1}$

\footnotetext{
1 Republik Indonesia, “Undang-Undang No. 20 Tahun 2003 tentang Sistem
} 
Dijelaskan pula di dalam firman Allah swt dalam QS. Al-Tahrim (66): 6

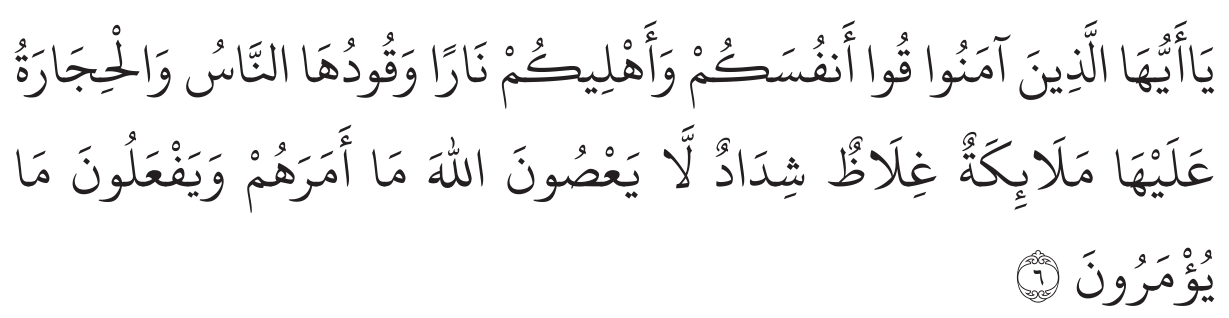

Terjemahnya:

Hai orang-orang yang beriman, peliharalah dirimu dan keluargamu dari api neraka yang bahan bakarnya adalah manusia dan batu; penjaganya malaikat-malaikat yang kasar, keras dan tidak mendurhakai Allah terhadap apa yang diperintahkan-Nya kepada mereka dan selalu mengerjakan apa yang diperintahkan. ${ }^{2}$

Orang tua dan masyarakat dalam hubungannya dengan penyelenggaraan pendidikan mempunyai peran yang penting yaitu sebagai mitra madrasah dalam penyelenggaraan pendidikan nasional, begitu juga penyelenggaraan pendidikan keagamaan.

Undang-undang Sistem Pendidikan Nasional pasal 30 UU No. 20 Tahun 2003 pendidikan keagamaan diselenggarakan oleh pemerintah dan/atau kelompok masyarakat dari pemeluk agama, sesuai dengan peraturan perundang-undangan. ${ }^{3}$

Proses pendidikan di madrasah dipengaruhi juga oleh adanya lingkungan masyarakat yang kondusif. Artinya lingkungan masyarakat juga memiliki peranan dalam pendidikan. Apabila lingkungan masyarakat mendukung akan keberadaan madrasah maka proses pendidikan akan berjalan dengan efektif dan kualitas pendidikan, baik umum maupun

Pendidikan Nasional (SISDIKNAS) dan Penjelasannya (Cet. I; Jogjakarta: Media Wacana Press, 2003), 20.

2 Departemen Agama RI, Al-Quran dan Terjemahnya (Semarang: Karya Toha Putra, 2002), 820 .

3 Undang-Undang No. 20 Tahun 2003 tentang Sistem Pendidikan Nasional (SISDIKNAS) dan Penjelasannya (Cet. I; Jogjakarta: Media Wacana Press, 2003), 23. 
agama Islam akan lebih bagus. Sehingga pendidikan, khususnya pendidikan agama Islam bisa menjadi alternatif pendidikan modern.

Sejalan dengan arah kebijakan otonomi dan desentralisasi yang ditempuh oleh pemerintah, maka tanggung jawab pemerintah daerah akan lebih meningkat termasuk dalam bidang manajemen pendidikan. ${ }^{4}$ Dan juga adanya perubahan paradigma pemerintah dari sentralisasi ke desentralisasi tersebut menghendaki adanya partisipasi masyarakat untuk membantu pemerintah daerah dalam mengembangkan potensi daerah di bidang pendidikan karena madrasah sebagai sistem sosial merupakan bagian integral dari sistem sosial yang lebih besar yaitu masyarakat. Hal ini merupakan upaya peningkatan kualitas sumber daya manusia di Indonesia yang merupakan pra syarat mutlak untuk mencapai tujuan pembangunan dimana pendidikan merupakan salah satu wahana untuk meningkatkan mutu sumber daya manusia.

Semakin banyak peserta didik, maka akan semakin banyak tenaga kependidikan, sarana dan prasarana lain yang di butuhkan dalam proses pembelajaran. Sumber Daya Manusia (SDM) atau tenaga kependidikan yang profesional dan kepedulian masyarakat yang sadar akan pendidikan agar dapat meningkatkan mutu pendidikan di madrasah tersebut dengan berpartisipasi.

Dari gambaran ini, Madrasah berupaya mempertahankan bahkan meningkatkan (bukan hanya kepercayaan dari masyarakat) kualitas pendidikan khususnya pendidikan agama Islam dengan melibatkan berbagai komponen masyarakat yaitu dengan terbentuknya komite madrasah yang terdiri dari unsur masyarakat madrasah dan masyarakat lingkungan madrasah.

Tidak dapat disangkal bahwa hubungan antara madrasah dan masyarakat merupakan hal yang sangat penting dalam penyelenggaraan kegiatan atau program yang berkaitan dengan pencapaian misi madrasah (pendidikan). Dalam kegiatan ini, bagaimana upaya untuk menumbuhkan sikap kepedulian sehingga keduanya saling membutuhkan. Masyarakat memerlukan madrasah sebagai lembaga pendidikan, sebaliknya

4 E. Mulyasa, Manajemen Berbasis Sekolah: Konsep Strategi dan Implementasi (Cet. I; Bandung: PT. Remaja Rosdakarya, 2002), iii. 
madrasah juga membutuhkan masyarakat sebagai salah satu komponen penting dalam penyelenggaraan pendidikan dalam hal ini, pendidikan memerlukan tenaga pendidik, peserta didik, lembaga pendidikan atau sekolah dan sumber daya pendidikan atau masyarakat. Hal tersebut membuktikan bahwa, tanpa adanya partisipasi masyarakat dalam proses pendidikan baik itu di lembaga pendidikan umum maupun di lembaga pendidikan agama, maka perkembangan pendidikan akan mengalami hambatan.

Sehubungan dengan penjelasan di atas, mencermati betapa pentingnya partisipasi masyarakat dalam peningkatan kualitas Pendidikan Agama Islam maka, penulis akan coba membahas secara mendalam dalam penulisan ini tentang urgensi partisipasi masyarakat dalam peningkatan kualitas Pendidikan Agama Islam (PAI) di Madrasah.

\section{Pembahasan}

\section{A. Kosep Dasar Pendidikan Agama Islam}

1. Pengertian Pendidikan Agama Islam

Pendidikan Islam yaitu sebuah proses yang dilakukan untuk menciptakan manusia-manusia yang seutuhnya yang beriman dan bertakwa kepada Allah swt serta mampu mewujudkan eksistensinya sebagai khalifah Allah swt dimuka bumi yang berdasarkan kepada alQuran dan Sunnah. Maka tujuan dalam konteks ini terciptanya manusia insan kamil. ${ }^{5}$ Istilah "Pendidikan Agama Islam" dan "Pendidikan Islam" dianggap sama, sehingga ketika seseorang berbicara tentang pendidikan Islam ternyata terbatas pada Pendidikan Agama Islam, atau sebaliknya ketika seseorang berbicara tentang Pendidikan Agama Islam justru yang dibahas di dalamnya adalah tentang pendidikan Islam. Padahal kedua istilah tersebut memilki substansi yang berbeda.

Pendidikan Agama Islam (PAI) sebagai mata pelajaran seharusnya dinamakan "agama Islam", karena yang diajarkan adalah agama Islam bukan pendidikan agama Islam. Nama kegiatannya atau usah-

5 Armai Arief, Pengantar Ilmu dan Metodologi Pendidikan Islam (Cet. I; Jakarta: Ciputat Pers, 2002), 16. 
usaha dalam pendidikan agama Islam disebut sebagai Pendidikan Agama Islam. Kata "pendidikan" ini ada pada dan mengikuti setiap mata pelajaran. Dalam hal ini PAI sejajar atau sekategori dengan pendidikan matematika nama mata pelajarannya adalah matematika dan seterusnya. Sedangkan pendidikan Islam adalah nama sistem, yaitu sistem pendidikan yang Islami, yang memilki komponenkomponen yang secara keseluruhan mendukung terwujudnya sosok muslim yang diidealkan.

Pendidikan Islam ialah pendidikan yang teori-teorinya disusun berdasarkan al-Qur'an dan hadis serta merupakan sistem pendidikan yang diselenggarakan atau didirikan dengan niat untuk mengejawantahkan ajaran dan nilai-nilai Islam dalam kegiatan pendidikannya. ${ }^{6}$

Menurut Mappanganro, pendidikan agama Islam di sekolah merupakan usaha bimbingan, pembinaan terhadap peserta didik, dalam meyakini, memahami, menghayati dan mengamalkan ajaran Islam sehingga menjadi manusia beriman dan bertakwa kepada Tuhan yang Maha Esa, Allah swt. ${ }^{7}$

Pemaparan di atas menggambarkan bahwa pendidikan agama Islam mencakup usaha yang dilaksanakan untuk membentuk atau membimbing jasmani dan rohani anak didik yang berdasarkan pada ajaran Islam serta memberikan gambaran kepada kita bahwa tujuan pendidikan agama Islam yaitu membentuk manusia yang beriman dan bertakwa kepada Allah swt sebagai tujuan hidup manusia itu sendiri serta merupakan aktualisasi dari hubungan manusia dengan Tuhan pencipta, hubungan manusia dengan sesama manusia serta hubungan alam raya ini.

2. Dasar-dasar Pendidikan Islam

Dalam menetapkan sumber pendidikan Islam dikemukakan tiga dasar utama dalam pendidikan Islam yaitu:

${ }^{6}$ Muhaimin, Pengembangan Kurikulum Pendidikan Agama Islam di Sekolah, Madrasah dan Pergurun Tinggi (Ed. I, Cet. II; Jakarta: PT Raja Grafindo Persada), 6-8.

7 Mappanganro, Pendidikan Islam di Sekolah (Cet. I; Ujung Pandang: Ahkam, 1996), 13. 
a. Al-Qur'an

Al-Qur'an adalah firman Allah yang diturunkan oleh Malaikat Jibril kepada Rasulullah saw dengan menggunakan lafadz Arab dan makna yang benar, agar ia menjadi hujjah bagi Rasul, bahwa ia benar-benar Rasulullah saw, menjadi undangundang bagi manusia, sebagai petunjuk dan sarana untuk melakukan pendekatan diri dan ibadah kepada Allah swt bagi pembacanya. ${ }^{8}$ Di dalamnya terkandung ajaran pokok yang dapat dikembangkan untuk keperluan seluruh aspek kehidupan melalui ijtihad. Ajaran yang terkandung dalam al-Qur'an menyangkut hubungan manusia dengan Tuhannya, dengan sesamanya dan hubungan dengan alam semesta.

b. As-Sunnah

As-Sunnah adalah segala sesuatu yang bersumber dari nabi, baik berupa perkataan, perbuatan, takrir, perangai, budi pekerti, perjalanan hidup baik sebelum diangkat menjadi Rasul maupun sesudahnya. ${ }^{9}$ Sunnah merupakan ajaran kedua sesudah al-Quran. Sunnah berisi petunjuk (pedoman) kemaslahatan hidup manusia dalam segala aspek, untuk membina umat menjadi manusia seutuhnya atau muslim yang bertakwa.

3. Ijtihad

Ijtihad adalah istilah fuqoha, yaitu berfikir dengan menggunakan seluruh ilmu yang dimiliki Islam untuk menetapkan atau menentukan suatu hukum syariat Islam dalam hal-hal yang ternyata belum tegas hukumnya oleh al-Qur'an dan Sunnah. ${ }^{10}$ Ijtihad dalam hal ini dapat saja meliputi seluruh aspek kehidupan termasuk aspek pendidikan. Ijtihad dalam pendidikan harus tepat berpedoman pada al-Qur'an dan Sunnah yang diolah oleh akal sehat dari para ahli pendidikan Islam. Ijtihad tersebut haruslah dalam hal-hal yang berhubungan langsung

8 Abdul Wahab Khalaf, Ilmu Ushul Fiqih (Cet. IX; Jakarta: Al-Majelis Al-A'la AlIndonesia Li Al- Dakwah Al-Islamiyah, 1972), 2.

9 Munzier Suparta, Ilmu Hadis (Cet. III; Jakarta:Raja Grafindo Persada, 2003), 7.

${ }^{10}$ Tengku Hasbi Ash-Shiddieqi, Pengantar Ilmu Fikih (Cet. II; Semarang: Riski Putra,1999), 200. 
dengan kebutuhan hidup di suatu tempat pada kondisi dan situasi tertentu. Teori teori pendidikan baru hasil ijtihad harus dikaitkan dengan ajaran Islam dan kebutuhan hidup. ${ }^{11}$

3. Tujuan Pendidikan Agama Islam

Berbicara tentang tujuan pendidikan juga mengajak kita berbicara tentang tujuan hidup. Tujuan hidup manusia yaitu diciptakan untuk menjadi khalifah, manusia yang dianggap sebagai khalifah Allah swt tidak dapat memegang peranan tanggung jawab sebagai khalifah kecuali kalau ia dilengkapi dengan potensi-potensi yang membolehkan berbuat demikian. Sebagimana firman Allah swt dalam QS. Al-Dzariat (51): 56

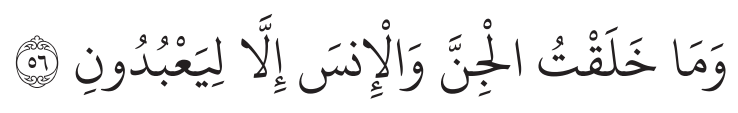

Terjemahnya:

Dan aku tidak menciptakan jin dan manusia melainkan supaya mereka menyembah-Ku. ${ }^{12}$

Ayat di atas menggambarkan bahwa manusia diciptakan untuk mengabdi (beribadah) kepada Allah swt sehingga, dalam proses pelaksanaan ibadah, manusia dituntut untuk melaksanakan ibadah tersebut dengan baik dan benar yang harus disertai ilmu agama, sedangkan ilmu agama hanya dapat diperoleh melalui pendidikan agama Islam.

Tujuan pendidikan Islam ditinjau dari segi historis memiliki dinamika seirama dengan kepentingan dan perkembangan masyarakat di mana pendidikan itu dilaksanakan. Contoh sederhana bahwa tujuan pendidikan Islam pada masa Rasulullah saw berbeda jauh dengan tujuan pendidikan Islam pada masa modern sekarang ini. Perkembangan inilah yang menyebabkan tujuan pendidikan Islam secara khusus mengalami dinamika seirama dengan perkembangan

${ }^{11}$ Zakiah Darajat, Ilmu Pendidikan Islam (Cet. III; Jakarta: Bumi Aksara, 1996), 2122.

${ }^{12}$ Departemen Agama RI, Al-Qur'an dan Terjemahnya (Semarang: Karya Toha Putra, 2002), 1030. 
zaman, namun tanpa melepaskan diri pada nilai-nilai Ilahiyah dan tujuan umumnya, yaitu sebagai ibadah. Akibat dinamikanya ini, para ahli muslim mencoba untuk memberikan definisi khusus terhadap pendidikan Islam.

Muhammad Fadhil Al-Jumaly yang memberikan defenisi batasan bahwa tujuan pendidikan Islam itu adalah membina kesadaran atas diri manusia itu sendiri dan atas sistem sosial yang Islami. Sikap dan rasa tanggung jawab sosialnya, juga terhadap alam ciptaan-Nya serta kesadarannya untuk mengembangkan dan mengelola alam ini bagi kepentingan dan kesejahteraan umat manusia. Dan yang penting lagi ialah terbinanya ma'rifat kepada Allah Pencipta alam semesta dengan beribadah dengan beribadah kepada-Nya dengan cara mentaati perintah-Nya dan menjauhi segala larangan-Nya. ${ }^{13}$

Ibnu Khaldun menyebutkan bahwa tujuan pendidikan Islam berupaya bagi pembentukan akidah/keimanan yang mendalam. Menumbuhkan dasar-dasar akhlak karimah melalui jalan agamis yang diturunkan untuk mendidik jiwa manusia serta menegakkan akhlak yang akan membangkitkan kepada perbuatan yang terpuji. Upaya ini sebagai perwujudan penyerahan diri kepada Allah swt pada tingkat individual, masyarakat dan kemanusiaan pada umumnya. ${ }^{14}$

Dari berbagai rumusan di atas, terdapat beberapa tujuan yang asasi bagi pendidikan Islam adalah sebagai berikut:

a. Tujuan umum, yakni tidak dapat dicapai kecuali setelah melalui proses pengajaran, pengalaman, penghayatan dan keyakinan akan kebenaran.

b. Tujuan operasional yaitu tujuan praktis yang hendak dicapai dengan sejumlah kegiatan pendidikan tertentu, yang menuntut kemampuandan keterampilan tertentu yang lebih ditonjolkan pada sifat penghayatan dan kepribadian. ${ }^{15}$

${ }^{13}$ Samsul Nizar, Pengantar Dasar-dasar Pemikiran Pendidikan Islam, (Cet. I; Jakarta: Gaya Media Pratama, 2001), 105.

${ }^{14}$ Ibid., 106.

${ }^{15}$ Ibid., 112. 
c. Tujuan sementara ialah tujuan yang akan dicapai setelah anak didik diberi sejumlah pengalaman tertentu yang direncanakan dalam suatu kurikulum pendidikan formal.

d. Tujuan akhir, yaitu terbentuknya insan kamil (manusia paripurna) yang mati dan akan menghadap tuhannya merupakan tujuan akhir dari proses pendidikan Islam. Dalam arti bahwa mati dalam keadaan muslim merupakan ujung dari takwa sebagai akhir dari proses hidup yang pasti berisikan kegiatan pendidikan. Tujuan akhir pendidikan agama Islam dapat dipahami dalam firman Allah swt dalam QS. Ali Imran (3): 102

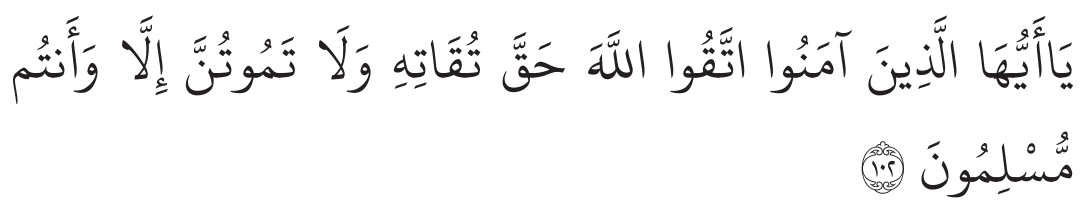

Terjemahnya:

Hai orang-orang yang beriman, bertakwalah kepada Allah sebenar-benar takwa kepada-Nya dan janganlah sekali-kali kamu mati melainkan dalam keadaan beragama Islam. ${ }^{16}$

Itulah akhir dari semua proses pendidikan yang dianggap sebagai tujuan akhir, yaitu mati dalam keadaan berserah diri kepada Allah sebagai muslim yang merupakan ujung dari takwa sebagai akhir dari proses hidup. Manusia beriman (insan kamil) yang mati dan mengahadap Tuhan-Nya merupakan tujuan akhir dari proses pendidikan agama Islam. ${ }^{17}$

\section{B. Partisipasi Masyarakat dalam Pendidikan Islam (Madrasah)}

1. Partisipasi Masyarakat

Partisipasi merupakan keterlibatan atau peran serta seseorang baik dilakukan secara individu maupun kelompok dalam suatu kegiatan tertentu. Partisipasi adalah keterlibatan emosi dan mental seseorang di dalam situasi kelompok yang mendorong mereka untuk

\footnotetext{
${ }^{16}$ Departemen Agama RI, Al-Qur'an dan Terjemahnya, 79.

${ }^{17}$ Zakiah Darajat, Ilmu Pendidikan Islam, 49.
} 
memberikan kontribusi terhadap tercapainya tujuan kelompok dan bertukar tanggung jawab diantara mereka. ${ }^{18}$

Istilah partisipasi masyarakat dapat diartikan sebagai peran serta semua anggota atau unsur yang terkait dalam masyarakat untuk melaksanakan suatu kepentingan bersama atau pekerjaan yang dimaksudkan untuk mempermudah tercapainya tujuan yang diharapkan atau dapat pula diartikan sebagai wadah atau forum sebagai ajang untuk pertemuan yang menganut keterbukaan dalam membahas persoalan yang ditandai dengan adanya interaksi masyarakat untuk merumuskan tujuan yang terbaik sehingga berhasil menemukan keputusan bersama. ${ }^{19}$

Jadi berdasarkan kutipan di atas, maka tidak berlebihan apabila penulis memberikan batasan bahwa partisipasi masyarakat adalah suatu bentuk kegiatan berupa turut serta secara bersama-sama dalam kelompok manusia yang memiliki tujuan yang sama. Sedangkan partisipasi masyarakat dalam peningkatan kualitas lembaga pendidikan Islam adalah merupakan suatu usaha yang dilakukan oleh kelompok manusia untuk memajukan lembaga pendidikan Islam.

Metode partisipasi dalam peningkatan kualitas lembaga pendidikan Islam sangat dibutuhkan. Melalui metode partisipasi mendorong setiap orang ke dalam suatu proses kelompok dengan tidak memandang umur, jenis kelamin, status sosial maupun latar belakang pendidikan. Melalui proses kelompok tersebut khsusnya bermanfaat untuk diperolehnya partisipasi masyarakat yang tidak memandang jenis kelamin untuk mengekspresikan pandangan atau pendapatnya, meskipun mereka tidak dapat membaca atau menulis. Metode partisipasi tersebut diciptakan untuk membangun rasa percaya diri dan tanggung jawab terhadap keputusan seseorang. Dengan metode partisipasi, masyarakat mencoba untuk membuat suatu proses perumusan keputusan menjadi mudah dan menyenangkan. Dengan

${ }^{18}$ R.A. Santoso Sastropoetro, Partisipasi Komunikasi, Persuasi dan Disiplin dalam Pembangunan Nasional (Ed. I, Cet. I; Bandung: Alumni, 1988), 13.

${ }^{19}$ Yusufhadi Miarso, Menyemai Benih Teknologi Pendidikan (Cet. I; Jakarta: Prenada Media, 2004), 706. 
metode partisipasi tersebut akan memudahkan untuk menyusun perencanaan lembaga pendidikan pada tingkat masyarakat sehingga dapat menghargai pengetahuan dan keterampilan yang dimiliki oleh masyarakat lainnya.

Undang-undang RI No. 20 Tahun 2003 tentang sistem Pendidikan Nasional menjelaskan bahwa pendidikan berbasis masyarakat merupakan penyelenggaraan pendidikan yang berdasarkan kekhasan agama, lingkungan sosial, budaya, aspirasi, dan potensi masyarakat sebagai perwujudan pendidikan dari, oleh, dan untuk masyarakat. ${ }^{20}$

Partisipasi masyarakat dalam pendidikan agama Islam di madrasah sudah sepatutnya dilakukan khususnya oleh masyarakat yang beragama Islam. Dalam Islam sendiri partisipasi disebut sebagai jihad karena hal ini merupakan bentuk kepedulian masyarakat terhadap berkembangnya agama Islam dan jihad fi sabilillah.

Sebagaimana firman Allah swt dalam QS. at-Taubah (9): 122

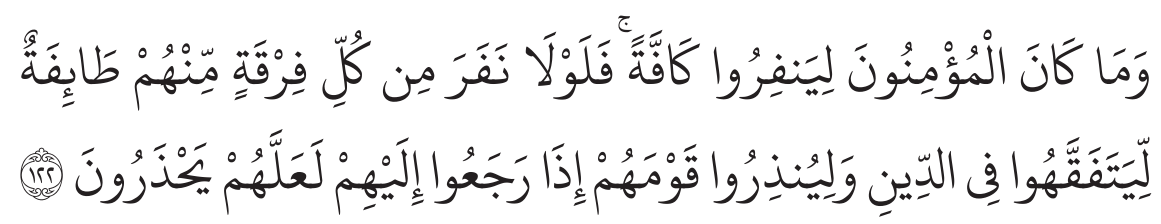

Terjemahnya:

Dan tidak sepatutnya orang-orang mukmin itu semuanya pergi (ke medan perang). Mengapa sebagian dari setiap golongan diantara mereka tidak pergi untuk memperdalam pengetahuan agama mereka dan untuk memberi peringatan kepada kaumnya apabila mereka telah kembali agar mereka dapat menjaga dirinya. ${ }^{21}$

Dari ayat ini mengandung arti bahwa umat Islam dituntut untuk mendukung jalannya pendidikan sebagaimana ayat di atas bahwa menuntut ilmu itu juga penting sebagaimana berjihad di medan perang. Dukungan itu dapat dilakukan dengan cara memberikan

${ }^{20}$ Republik Indonesia, “Undang-undang RI No. 20 Tahun 2003” tentang Sistem Pendidikan Nasional dan Penjelasannya (Cet. I; Jogyakarta: Media Wacana Press, 2003), 36.

${ }^{21}$ Departemen Agama RI, Al-Quran dan Terjemahnya, 301. 
segala kemampuan yang dimilikinya ke jalan Allah swt. Maka dari itu sumbangsi masyarakat Islam terhadap pendidikan juga dapat disebut sebagai jihad. Yang dimaksud jihad disini adalah bukan semata-mata mengangkat senjata, melainkan dengan sungguh-sungguh usaha dan kegiatan menuju ke arah kemajuan dan kesempurnaan di jalan Allah yang terkenal dengan tugas amar ma'ruf nahi mungkar. Sebagaimana firman Allah QS. Ali Imran (3): 110

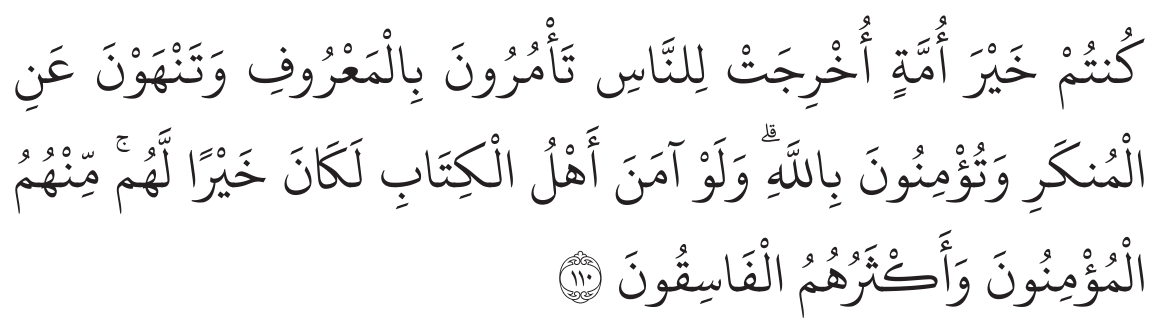

Terjemahnya:

Kamu adalah umat yang terbaik yang dilahirkan untuk manusia, menyuruh kepada yang ma'ruf, dan mencegah dari yang munkar, dan beriman kepada Allah. sekiranya ahli Kitab beriman, tentulah itu lebih baik bagi mereka, di antara mereka ada yang beriman, dan kebanyakan mereka adalah orang-orang yang fasik. ${ }^{22}$

Pada dasarnya partisipasi masyarakat memiliki tiga konsep yang mana madrasah dan masyarakat merupakan partnership (mitra) dalam berbagai aktifitas yang berkaitan dengan aspek-aspek pendidikan yaitu:

a. Madrasah dengan masyarakat merupakan satu keutuhan dalam menyelenggarakan pendidikan dan pembinaan pribadi peserta didik.

b. Madrasah dengan tenaga kependidikan menyadari pentingnya kerjasama dengan masyarakat bukan hanya dalam melakukan pembaruan tetapi juga dalam menerima konsekuensi dan dampaknya serta mencari solusi dan pemecahannya.

${ }^{22}$ Ibid., 65. 
c. Madrasah dengan masyarakat sekitar memiliki andil dan mengambil bagian serta dan bantuan dalam pendidikan di madrasah untuk mengembangkan berbagai potensi yang ada sesuai dengan harapan peserta didik. ${ }^{23}$

Para pakar pendidikan setuju bahwa masyarakat, terutama orang tua memberikan sumbangan penting bagi pekerjaan mereka. Partisipasi yang diminta biasanya berupa dukungan dari masyarakat atas apa yang sedang di coba dilakukan madrasah. Yakni para guru dan kepala madrasah dukungannya pun berupa penyediaan tenaga kerja dan meterial bangunan dan pemeliharaan gedung yang menjamin bahwa para siswa mengerjakan pekerjaan rumah mereka.

Tingkat partisipasi masyarakat yang rendah dianggap sebagai kegagalan masyarakat untuk menghargai nilai pendidikan. Pendidikan harus dikaitkan kepada kebutuhan-kebutuhan produksi masyarakat, madrasah membantu memikul biaya operasionalnya sendiri dan menjadi bagian integral dalam komunitas yang mereka layani. ${ }^{24}$

Tujuan utama peningkatan partisipasi adalah:

1). Meningkatkan dedikasi/kontribusi stakeholders terhadap penyelenggaraan pendidikan di madrasah, baik dalam bentuk jasa (pemikiran/intelektualitas, keterampilan), moral, finansial, dan material/barang.

2). Memberdayakan kemampuan yang ada pada stakeholders bagi pendidikan untuk mewujudkan tujuan pendidikan nasional.

3). Meningkatkan peran stakeholders dalam penyelenggaraan pendidikan di madrasah, baik sebagai advisor, supporter, mediator, controller, resource linker, and education provider.

4). Menjamin agar setiap keputusan dan kebijakan yang diambil benar-benar mencerminkan aspirasi stakeholder dan menjadikan

${ }^{23}$ Philip Robinson, Beberapa Perspektif Sosiologi Pendidikan (Cet. I; Jakarta: Rajawali, 1986), 341.

${ }^{24}$ Ibid., 34. 
aspirasi stakeholders sebagai panglima bagi penyelenggaraan pendidikan di madrasah. ${ }^{25}$

Sebagai umat Islam dituntut untuk selalu berjuang/berjihad dengan sungguh-sungguh di jalan Allah, sesuai dengan kemampuan yang dimilikinya. Apabila mampu dengan tangannya hendaklah mau dengan ikhlas menyumbangkan tenaganya, apabila mampu dengan lisannya, maka mereka harus berani mengatakan dengan tegas yang hak dan yang bathil, mencarikan solusi yang baik untuk kebenaran di jalan Allah seperti sebagai ustadz, guru, dan lain-lain.dan apabila hanya mampu dengan hatinya, maka mereka harus meyakini dengan seyakain-yakinnya apa yang diperintah-Nya dan apa yang dilarangNya.

Menurut pandangan Islam, pada dasarnya manusia memiliki dua bentuk kemampuan yang dapat dipergunakan untuk berpartisipasi (jihad) di jalan Allah, yaitu berupa harta dan jiwa. Sebagaimana firman Allah Swt dalam QS. Al-Hujurat (49): 15

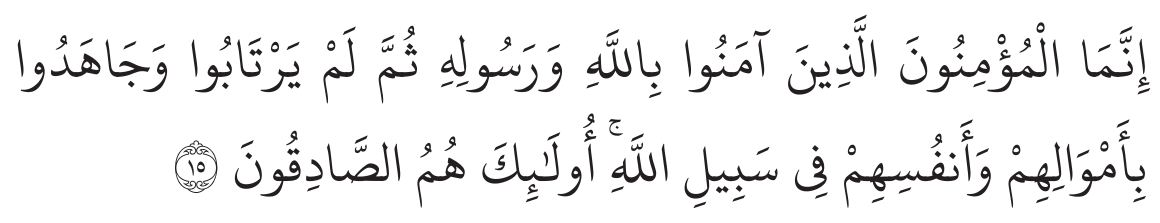

Terjemahnya:

Sesungguhnya orang-orang yang beriman itu hanyalah orang-orang yang percaya (beriman) kepada Allah dan Rasul-Nya, Kemudian mereka tidak ragu-ragu dan mereka berjuang (berjihad) dengan harta dan jiwa mereka pada jalan Allah. mereka Itulah orangorang yang benar. ${ }^{26}$

2. Faktor-faktor yang Perlu dalam Partisipasi Masyarakat untuk Peningkatan Kualitas Pendidikan Agama Islam di Madrasah

${ }^{25}$ Surya Dharma, Manajemen Kinerja, Falsafah Teori dan Penerapannya (Cet. III; Yogyakarta: 2010), 68.

${ }^{26}$ Departemen Agama RI, Al-Quran dan Terjemahnya, 518. 
Masyarakat adalah kelompok orang yang bertanggung jawab terhadap pendidikan anak-anaknya. Jadi dalam hal ini, dapat diketahui bahwa Masyarakat atau penduduk di dalam lembaga pendidikan nonformal adalah manusia dewasa yang mengemban amanah, kepercayaan sehingga secara sadar dan bertanggung jawab dalam proses pelaksanaan pendidikan bagi si anak dalam keluarganya.

Masyarakat selaku pengguna jasa pendidikan memiliki kewajiban untuk mengembangkan serta menjaga kelangsungan penyelenggaraan proses pendidikan.

Undang-undang Sitem Pendidikan Nasional No. 20 Tahun 2003, pendidikan merupakan tanggung jawab bersama antara pemerintah, masyarakat dan keluarga. ${ }^{27}$

Peran serta masyarakat dalam pendidikan meliputi peran serta perseorangan, kelompok, keluarga, organisasi profesi, pengusaha dan organisasi kemasyarakatan dalam penyelenggaraan dan pengendalian mutu pendidikan. selain itu, masyarakat dapat berperan serta sebagai sumber, pelaksana dan pengguna hasil.

Masyarakat sebagai pendidik secara tidak langsung di madrasah merupakan bagian utama dalam menentukan tercapainya tujuan pendidikan meskipun tidak terlibat langsung dalam proses belajar mengajar. Adapun faktor-faktor yang perlu dalam melibatkan partisipasi masyarakat untuk peningkatan kualitas pendidikan dapat dikelompokkan dalam empat bagian, yaitu: keterbukaaan, interaksi, keputusan bersama, dan pemantauan. ${ }^{28}$ Keempat faktor yang disebutkan merupakan sebuah bentuk atau ciri-ciri yang dimiliki oleh masyarakat. Dengan mengetahui ciri-ciri yang dimiliki oleh masyarakat, maka otomati dapat mempermudah mengetahui bentuk partisipasi yang dapat dilakukan terhadap masyarakat untuk melibatkan mereka berpartisipasi dalam dunia pendidikan.

${ }^{27}$ Republik Indonesia, Undang-undang No. 20 Tahun 2003 tentang Sistem Pendidikan Nasional (SISDIKNAS) dan Penjelasannya (Cet. I; Jogjakarta: Media Wacana Press, 2003), 23.

${ }^{28}$ Ibid., 706. 
Menurut R.A. Santoso Sastropoetro, ada beberapa faktor yang mempengaruhi masyarakat untuk ikut berpartisipasi terhadap pendidikan di madrasah yaitu:

a. Minat dan motivasi masyarakat untuk mendapatkan pendidikan. Dengan mengenyam pendidikan masyarakat berharap memiliki kemampuan membaca, menulis, berhitung dan mendapatkan kedudukan sosial dan percaya terhadap diri sendiri.

b. Untuk merubah tingkah laku menjadi lebih baik. Dengan mendapatkan pendidikan di madrasah masyarakat berharap anakanak mereka menjadi lebih baik dalam bertingkah laku di tengah masyarakat. $^{29}$

Hubungan madrasah dengan madrasah (sekolah) lain diharapkan dapat memiliki keuntungan satu sama lain. Hubungan tersebut merupakan hubungan kerja yang bersifat paedagogis, sosiologis, dan produktif. Oleh karena itu, kepala madrasah, guru-guru dan pengurus yayasan hendaknya selalu bekerjasama untuk memanfaatkan sumber daya di dalam masyarakat yang diperlukan madrasah.

Menurut Basrowi yang dikutip Siti Irene Astuti Dwiningrum, partisipasi masyarakat dilihat dari bentuknya dapat dibedakan menjadi dua, yaitu:

1. Partisipasi fisik

Partisipasi fisik adalah partisipasi masyarakat (orang tua) dalam bentuk menyelenggarakan usaha-usaha pendidikan, seperti mendirikan dan menyelenggarakan usaha madrasah.

2. Partisipasi non fisik

Partisipasi non fisik adalah partisipasi keikutsertaan masyarakat dalam menentukan arah dan pendidikan nasional dan meratanya animo masyarakat untuk menuntut ilmu pengetahuan melalui pendidikan, sehingga pemerintah tidak ada kesulitan mengarahkan rakyat untuk memperoleh pendidikan. ${ }^{30}$

${ }^{29}$ R.A. Santoso Sastropoetro, Partisipasi Komunikasi, Persuasi dan Disiplin dalam Pembangunan Nasional, 22.

${ }^{30}$ Siti Irene Astuti Dwiningrum, Desentralisasi dan Partisipasi Masyarakat dalam 
Adapun bentuk-bentuk partisipasi masyarakat dalam pendidikan yaitu:

a. Kesiapan SDM secara profesional.

b. Stakeholder mendukung program madrasah.

c. Menghadiri pertemuan madrasah untuk mengetahui perkembangan siswa.

d. Membantu siswa belajar. ${ }^{31}$

\section{Penutup}

Konsep dasar pendidikan Agama Islam yaitu pendidikan yang teoriteorinya disusun berdasarkan Al-Qur'an dan hadis serta merupakan sistem pendidikan yang diselenggarakan atau didirikan dengan niat untuk mengejawantahkan ajaran dan nilai-nilai Islam dalam kegiatan pendidikannya, menumbuhkan dasar-dasar akhlak karimah melalui jalan agamis yang diturunkan untuk mendidik jiwa manusia serta menegakkan akhlak yang akan membangkitkan kepada perbuatan yang terpuj. Tujuan pendidikan Islam pada hakikatnya membina kesadaran atas diri manusia itu sendiri dan atas sistem sosial yang Islami. Sikap dan rasa tanggung jawab sosialnya, juga terhadap alam ciptaan-Nya serta kesadarannya untuk mengembangkan dan mengelola alam ini bagi kepentingan dan kesejahteraan umat manusia.

Partisipasi masyarakat dalam pendidikan Islam yaitu masyarakat dituntut untuk mendukung jalannya pendidikan sebagaimana berjihad di medan perang. Dukungan itu dapat dilakukan dengan cara memberikan segala kemampuan yang dimilikinya seperti keterbukaaan, interaksi, keputusan bersama, dan pemantauan terhadap peserta didik dan lingkungan pendidikan, yang mana pada dasarnya partisipasi masyarakat memiliki tiga konsep yang mana madrasah dan masyarakat merupakan partnership (mitra) dalam berbagai aktifitas yang berkaitan dengan aspekaspek pendidikan. Partisipasi masyarakat juga dapat dilihat dari segi

Pendidikan (Cet. I; Yogyakarta: Pustaka Pelajar, 2011), 58.

${ }^{31}$ Ibid., 60. 
bentuk partisipasinya berupa partisipasi fisik menyelenggarakan usaha madrasah dan non fisik dorongan atau support animo masyarakat untuk menuntut ilmu pengetahuan melalui pendidikan.

\section{Daitar Pustaka}

Arief, Armai. Pengantar Ilmu dan Metodologi Pendidikan Islam. Cet. I; Jakarta: Ciputat Pers, 2002.

Darajat, Zakiah Ilmu Pendidikan Islam. Cet. III; Jakarta: Bumi Aksara, 1996.

Departemen Agama RI. Al-Qur'an dan Terjemahnya. Semarang: Karya Toha Putra, 2002.

Dharma, Surya. Manajemen Kinerja, Falsafah Teori dan Penerapannya. Cet. III; Yogyakarta: 2010.

Dwiningrum, Siti Irene Astuti. Desentralisasi dan Partisipasi Masyarakat dalam Pendidikan. Cet. I; Yogyakarta: Pustaka Pelajar, 2011.

Khalaf, Abdul Wahab. Ilmu Ushul Fiqih. Cet. IX; Jakarta: Al-Majelis AlA'la Al-Indonesia Li Al- Dakwah Al-Islamiyah, 1972.

Mappanganro. Pendidikan Islam di Sekolah. Cet. I; Ujung Pandang: Ahkam, 1996.

Miarso, Yusufhadi. Menyemai Benih Teknologi Pendidikan. Cet. I; Jakarta: Prenada Media, 2004.

Muhaimin. Pengembangan Kurikulum Pendidikan Agama Islam di Sekolah, Madrasah dan Pergurun Tinggi,. Ed. I, Cet. II; Jakarta: PT Raja Grafindo Persada

Mulyasa, E. Manajemen Berbasis Sekolah: Konsep Strategi dan Implementasi. Cet. I; Bandung: PT. Remaja Rosdakarya, 2002.

Nizar, Samsul. Pengantar Dasar-dasar Pemikiran Pendidikan Islam. Cet. I; Jakarta: Gaya Media Pratama, 2001.

Republik Indonesia. “Undang-Undang No. 20 Tahun 2003 tentang Sistem Pendidikan Nasional (SISDIKNAS) dan Penjelasannya. Cet. I; Jogjakarta: Media Wacana Press, 2003. 
Robinson, Philip. Beberapa Perspektif Sosiologi Pendidikan. Cet. I; Jakarta: Rajawali, 1986.

Sastropoetro, R.A. Santoso. Partisipasi Komunikasi, Persuasi dan Disiplin dalam Pembangunan Nasional. Ed. I, Cet. I; Bandung: Alumni, 1988. Ash-Shiddieqi, Tengku Hasbi. Pengantar Ilmu Fikih. Cet. II; Semarang: Riski Putra, 1999.

Suparta, Munzier. Ilmu Hadis. Cet. III; Jakarta:Raja Grafindo Persada, 2003.

Undang-Undang No. 20 Tahun 2003 tentang Sistem Pendidikan Nasional (SISDIKNAS) dan Penjelasannya. Cet. I; Jogjakarta: Media Wacana Press, 2003. 